\author{
Olga M. Pliasun \\ orcid.org/0000-0003-2674-5361
}

\title{
LINGUISTIC PALETTE OF UKRAINIAN SCIENTIFIC IMAGE FORMING POTENTIAL IN WORLD MEDIA
}

\begin{abstract}
The paper introduces the most relevant issues of linguistic imageology. In particular, the author focuses on the problem of forming successful image strategies as a set of verbalised image actions aimed at creating a positive image of a country in media. The prospects of the investigated problem are evidenced by numerous scientific explorations conducted in the last decade in leading European and Asian scientific centers. In this study, the scholar explores the works of Spanish linguists (P. Rodriguez, A. Santana Talavera, A. Rodriguez Darias etc.) devoted to the problem of developing the so-called "strategic codes" of successful state image. It is stated that the appeal to subconscious, emotional, mythical and cultural codes is the most effective, which is explained by powerful suggestive potential of modern media. Therefore, in media discourse the author proposes to analyze symbolic association code that is able to relate in the recipient's consciousness a particular symbolic object/precedent phenomenon to the country to which it belongs, particularly, Ukraine. In this context, the author considers linguistic specificity of representation of Ukraine's symbolic figures in state image strategies, primarily, in the image strategy of appealing to values, which is based on axiological principles. The thesis about powerful image forming potential of mathematical (M. Ostrogradsky, G. Voroniy, M. Viazovska) medical, biological (I. Mechnikov, D. Zabolotny, O. Bogomolets, V. Vernadsky, O. Brovarets, M. Rodnina) and other Ukrainian scientific schools is argued. A wide arsenal of linguistic tools used by media to create effective image texts is analyzed. The main image forming markers in such publications are, as a rule, emotionally-evaluative epithetical, metaphorical and peripheral constructions with distinctly positive semantics. Summing up the results, the author concludes that there is a need for professional linguistic analysis of image texts about Ukraine in modern media. In this context, media linguistic imageology, that is able to explain linguistic mechanisms for
\end{abstract}


constructing effective image texts, seems to be one of the most promising research directions of modern neolinguistics.

Key words: linguistic imageology, image of Ukraine, image strategies, image text, image forming potential.

Information about the author: Pliasun Olga Mykolayivna - a PhD student of the department of stylistics and language communication; Institute of philology; Taras Shevchenko National University of Kyiv.

E-mail:olga_2511@ukr.net

\author{
Плясун О.М. \\ orcid.org/0000-0003-2674-5361
}

\title{
ЛІНГВІСТИЧНА ПАЛІТРА ІМІДЖЕФОРМУВАЛЬНОГО ПОТЕНЦАЛУ УКРАЇНСЬКОЇ НАУКИ У СВІТОВИХ МЕДІА
}

Анотація. У статті аналізуються актуальні питання лінгвістичної іміджелогії. Зокрема, авторська увага зосереджена на проблемі формування успішних іміджевих стратегій як комплексу вербалізованих іміджевих дій, спрямованих на створення позитивного іміджу краӥни в медіа. Перспективність означеної проблематики у модерній лінгвістиці засвідчують численні наукові розвідки, які проводяться в останнє десятиліття в провідних європейських та азійських наукових центрах. $У$ цььму аспекті науковий інтерес становлять дослідження іспанських лінгвістів (П. Родрігес, A. Сантана Талавера, А. Родрігес Даріас та ін.), зосереджені навколо проблем розроблення "стратегічних кодів" ефективного державного іміджу. У медійному просторі, на переконання автора, найбільш ефективною є апеляція до підсвідомого, емотивного, міфічного та культурного кодів, щуо зумовлено потужним сугестивним потенціалом сучасних ЗМІ. Окрім того, досить успішним у мас-медійному дискурсі $\epsilon$ звернення до запропонованого автором коду символічної асоціацї, здатного пов'язувати у свідомості реципіснта той чи інший символізований об'єкт / прецедентний феномен із краӥною, до якої він належить, зокрема Украӥною. У иьому контексті автор аналізує мовну специфіку репрезентації знакових для України фігур у державних іміджевих стратегіях, насамперед, в іміджевій стратегії апеляції до цүінностей, яка заснована на аксіологічних принциипах. Аргументується теза про потужний іміджеформувальний потенціал 
Актуальні проблеми української лінгвістики: теорія і практика

математичної (М. Остроградський, Г. Вороний, М. В'язовська), медико-біологічної (І. Мечников, Д. Заболотний, О. Богомолеиь, В. Вернадський, О. Броварещь, М. Родніна) та ін. українських наукових шкіл. Аналізується широкий арсенал мовних засобів, які використовуються журналістами для створення ефективних іміджевих текстів. Основними іміджеформувальними маркерами в таких публікаиіях $\epsilon$, як правило, емоційно-оиінні епітетні, метафоричні та перифрастичні конструкиії з виразною позитивною семантикою. Таким чином, робиться висновок про необхідність фахового лінгвістичного аналізу іміджевих текстів про Украйну у сучасних 3МI. У иъьму аспекті медіалінгвоіміджелогія, яка здатна пояснити мовні механізми їх конструювання, постає в сучасній неолінгвістиці однією з найбільш актуальних дослідницьких парадигм.

Ключові слова: лінгвістична іміджелогія, імідж Украӥни, іміджеві стратегї̈, іміджевий текст, іміджеформувальний потенціал.

Інформація про автора: Плясун Ольга Миколаївна - аспірант кафедри стилістики та мовної комунікаиіі; Інститут філології; Київський начіональний університет імені Тараса Шевченка.

Електронна адреса: olga_2511@ukr.net

\section{Плясун О.Н.}

orcid.org/0000-0003-2674-5361

\section{ЛИНГВИСТИЧЕСКАЯ ПАЛИТРА ИМИДЖЕФОРМИРУЮЩЕГО ПОТЕНЦИАЛА УКРАИНСКОЙ НАУКИ В МИРОВЫХ МЕДИА}

Аннотация. В статье анализируются актуальные вопросы лингвистической имиджелогии. В частности, авторское внимание сосредоточено на проблеме формирования успешных имиджевых стратегий как комплекса вербализованных имиджевых действий, направленных на создание позитивного имиджа страны в медиа. Перспективность обозначенной проблематики в модерной лингвистике подтверждают многочисленные научные исследования, которые проводятся в последнее десятилетие в ведущчих европейских $u$ азиатских научных иентрах. В этом аспекте научный интерес представляют исследования испанских лингвистов (П. Родригес, А. Сантана Талавера, А. Родригес Дариас и др.), сосредоточенные вокруг проблем разработки "стратегических кодов" эффективного 
государственного имиджа. В медийном пространстве, по мнению автора, наиболее эффективна апеллячия $\kappa$ подсознательному, эмотивному, мифическому и культурному коду, что обусловлено мощным сугzестивным потенциалом современных СМИ. Кроме того, достаточно успешным в масс-медийном дискурсе является обращение $\kappa$ предложенному автором коду символической ассоциации, способному связывать в сознании речиииента тот или иной символизированный объект/прецедентный феномен со страной, $к$ которой он относится, в частности Украиной. В этом контексте автор анализирует языковую спечифику репрезентации знаковых для Украины фигур в государственных имиджевых стратегиях, прежде всего, в имиджевой стратегии апелляиии к иенностям, основанной на аксиологических принципах. Аргументируется тезис о мощном имиджеформирующем потенциале математической (М. Остроградский, Г. Вороной, М. Вязовская), медико-биологической (И. Мечников, Д. Заболотный, А. Богомолеи, В. Вернадский, О. Бровареи, М. Роднина) и др. украинских научных школ. Анализируется широкий арсенал языковых средств, используемых журналистами для создания эффективных имиджевых текстов. Основными имиджеформируюшими маркерами в подобных публикациях являются, как правило, эмочионально-оченочные эпитетные, метафорические и перифрастические конструкиии с выразительной положительной семантикой. Таким образом, делается вывод о необходимости профессионального лингвистического анализа имиджевых текстов об Украине в современных СМИ. В этом аспекте медиалингвоимиджелогия, способная объяснить языковые механизмы их конструирования, представляется одной из наиболее актуальных исследовательских парадигм современной неолингвистики.

Ключевые слова: лингвистическая имиджелогия, имидж Украины, имиджевые стратегии, имиджевый текст, имиджеформирующий потенциал.

Информация об авторе: Плясун Ольга Николаевна - аспирант кафедры стилистики и языковой коммуникации; Институт филологии; Киевский нащиональный университет имени Тараса Шевченко.

Электронный адрес: olga_2511@ukr.net

One of the most topical issues of modern linguistic imageology is the problem of constructing effective state image strategies, which we define as a set of verbalised image actions aimed at creating a 
positive national and international state's image.Therefore, medialinguistic aspect of the investigated question is related to the creation of a favorable country's image in media that represent main socio-cultural tendencies as well as possess a powerful arsenal of various verbalized methods of influencing mass audience.

The prospects of media direction of image studies are evidenced by numerous investigations conducted in 2010-2019 at leading universities of Ireland [2], Spain [3], Lithuania [5], Indonesia [6], Taiwan [4] etc. Thus, the research attention of Taiwanese scholars Hsiang-Ming Lee, Ching-Chi Lee and Cou-Chen $\mathrm{Wu}$ is focused on linguistic analysis of formation of a country's brand image strategy and study of linguistic potential of recreational state image strategies [4]. In turn, scientific research of Spanish linguists P. Rodriguez, A. Santana Talavera and A. Rodriguez Darias [3] is focused on the problems of developing the so-called "strategic codes" of successful state image. In media space, in our view, the most effective is the appeal to:

* unconscious code aimed at creating special subliminal messages that affect the subconscious level. We note that the important role of the subconscious level is also emphasized in G. Pocheptsov's scientific observations [8], where the scholar argues that the appeal to non-rational forms of cognition helps to bypass the filter of the audience and thus makes it possible to use suggestive technologies in the image text;

* emotive code, which regulates the recipient's feelings and emotions and in such a way determines his/her emotional response to the message;

* mythical code, capable of modeling the idea of the country's past and future. In this context, it should be emphasized that the creation and perpetuation of state myths is an extremely effective image technology and an important part of the image mythologization strategy;

* cultural code that focuses the recipient's attention on the uniqueness of the state's historical and cultural heritage;

* symbolic association code (author's definition) that is able to relate in the recipient's consciousness a particular symbolic 
object/precedent phenomenon to the country to which it belongs, in our case, Ukraine.

We emphasize that this code is successfully used in territorial image making. For instance, the Eiffel Tower, the Louvre, NotreDame de Paris are connected in our consciousness with Paris, the Pantheon, the Colosseum, the Trevi Fountain - with Rome, Saint Sophia Cathedral, St. Andrew's Church, Kyiv Pechersk Lavra - with Kyiv etc. Similarly, symbolic associations are formed with precedent figures, which is important for constructing a positive state image. In this context, it is necessary to mention innovative scientific discoveries of P. Kapitsa (the Nobel Prize winner, one of the founders of low temperature physics and physics of strong magnetic fields), an aircraft designer I. Sikorsky (the creator of first successful mass-produced helicopter, the Sikorsky R-4), a bacteriologist V. Khavkin, who invented vaccines against cholera and bubonic plague, a programmer S. Wozniak, a co-founder of Apple Inc., the world-renowned economist B. Havrylyshyn, thanks to whom the World Economic Forum appeared, a programmer M. Levchin, former vice president of Google LLC in the field of engineering, developer of PayPal payment system and many other scientists, writers, musicians, directors, dancers, athletes who are Ukrainians by origin. Recently a polish writer of Ukrainian descent O. Tokarchuk has won the Nobel Prize in literature (2018). Obviously, such events have a positive influence on the formation of Ukraine's image in world media. Undoubtedly, such significant achievements of Ukrainians have an image character and, thus, can be successfully used in Ukrainian state image strategies.

In the process of linguistic modeling of Ukraine's image it is important to take into account the experience of successfully implemented image strategies of other countries. In particular, a comparative analysis of effective image strategies of Lithuania, Estonia and Finland conducted by Lithuanian scientists A. Junevičius and P. Mindaugas [5] proves that the process of state image improving requires the use of a clearly planned strategic approach, in the framework of which it is necessary to appeal to the so-called image-forming elements - symbolic events, which are positively 
evaluated in world information space. To such events Lithuanian linguists logically enlist help of neighboring countries, participation in the fight for human rights, solving environmental problems, climate change problems, etc. It is clear that the linguistic component of constructing effective image strategies involves the creation of special image texts that implement the studied meanings.

The Slavic vector of verbalized image strategies research (I. Vasylenko [9; 10], E. Alekseeva [1], G. Pocheptsov [8] etc.) is aimed at developing the basic mechanisms for constructing state image and highlighting the main directions of state image strategy.

In this aspect, scientists analyze the concept of soft power that was proposed in 1990 by an American political scientist, professor at the John F. Kennedy Harvard Institute of Public Administration J. Nye [7] to indicate such a line of behavior which is based on indirect ways of getting the desired results, the so-called "laws of attraction". In linguistic imageology, "soft power" is interpreted by Slavic linguists in axiological discourse - as the power of cultural symbols, achievements, ideals of a country which are verbalized in media and thus make the whole world speak of it positively. It is only logical that if a country promotes human values, values of culture, science, art, etc., it causes attraction, which, in turn, positively affects its external and internal image.

To understand the linguistic mechanisms of constructing state image, it is essential to study the concept of symbolic capital of culture, proposed in the 1990 s by a French philosopher and sociologist P. Bourdieu [2]. According to P. Bourdieu, the symbolic capital of culture is a kind of "trustworthy value" that depends on public perceptions, thoughts and beliefs. Given its axiological function, society gives culture the so-called "credit of trust", resulting in its gaining symbolic power over society. Thus, an integral part of the symbolic capital of culture is state image, which is based on the faith of people who consider this capital valuable for themselves [10, p. 28].

Considering that state image combines various forms of symbolic capital, this view of the problem under study is, in our opinion, quite understandable. Precedent figures, cultural objects, spiritual heritage 
present the country at both internal (national) and external (international) levels, thus forming its state image. A linguist in this context needs to pay attention to a special role of precedent figures important for a country's culture and history as well as analyze linguistic specificity of their representation in state image strategies. Undoubtedly, precedent names are well presented in modern media which have manipulative ability and suggestive potential of promoting certain meanings in mass consciousness.

In our opinion, high image potential of mathematical (M. Ostrogradsky, G. Voroniy, M. Viazovska) medical, biological (I. Mechnikov, D. Zabolotny, O. Bogomolets, V. Vernadsky, O. Brovarets, M. Rodnina) and other Ukrainian scientific schools can be used within the framework of the image strategy of appealing to values which is based on axiological principles that are important not only for image makers but also for media linguists working with texts. In this context media publications dedicated to world achievements of Ukrainian researchers clearly demonstrate powerful image forming potential of Ukrainian science.

Particularly, a significant figure in the mathematical field was a Ukrainian world-class scientist M. Ostrogradsky (1801-1861) - one of the founders of the St. Petersburg mathematical school, author of about 100 scientific works, known for his studies in number theory, probability theory and variational calculus. The Ostrogradsky method, Gauss-Ostrogradsky theorem is used by leading foreign researchers. In 2001, the scientist was included in the UNESCO list of world outstanding mathematicians. The importance of M. Ostrogradsky's scientific achievements is also emphasized by contemporary national and world media. Positive evaluation of the researcher's scientific results in mass media is expressed not only by extralinguistic, but also by linguistic means: emotional-evaluative epithets, metaphorical constructs, etc., which, therefore, testify to the possibility of using the analyzed precedent figure in state image strategy of appealing to values: "On September 24, 1801, Mykhailo Ostrogradsky, a prominent Ukrainian mathematician, was born. Recognized by the entire scientific world, he is a member of Russian, Roman, Turin and American academies and one of the first 
Актуальні проблеми української лінгвістики: теорія і практика

among the Slavs to become a member of French Academy of Sciences" [12], "Ostrogradsky's educational views were ahead of their time in many respects, particularly his program for the education of children between the ages of seven and twelve, which is expounded in Considérations sur l'enseignement", "Ostrogradsky contributed significantly to the development of the method of separating variables that was so successfully applied by Fourier in his work on the conduction of heat (1822)" [13] etc.

The name of a Ukrainian mathematician G. Voroniy (1868-1908) is also precedent for Ukrainian science. Mathematical objects designed by the scholar (Voroniy diagrams) are used for creation of artificial intelligence, robots construction, radiation physics, astrophysics, crystallography etc. In linguistic imageology, a wide arsenal of linguistic tools used by media to create effective image texts attracts the research attention, among which the most frequent are evaluative epithets: "April 28 marks the $150^{\text {th }}$ anniversary of the birth of Georgiy Voroniy (1868-1908), a world-renowned mathematician and Ukrainian by birth. By the decision of the Verkhovna Rada of Ukraine of February 8, 2018 (draft № 7274), the name of Georgiy Voroniy is included in the list of prominent persons whose anniversaries are celebrated at the state level" [14], metaphorical constructions: "Scientists of such a scale as Georgy Voroniy raise the rating of the nation as a whole" [14] etc.

Recent discovery of a Ukrainian mathematician M. Viazovska (born 1984) is also significant for linguistic modeling of a positive Ukraine's image. The scientist managed to "solve the mathematical problem of centuries", i.e. the problem of finding the densest packing of spheres. In 2016, she received the prestigious Salem Prize. It is only logical that the researcher's name immediately appeared in Ukrainian and foreign media with positive evaluations of her scientific achievements. We emphasize that image publications dedicated to the discovery of M. Viazovska are characterized by high metaphoricity which enhances suggestive influence on mass recipient: "A Ukrainian Maryna Viazovska made a breakthrough in mathematics" [15], "How Maryna Viazovska cracked the sphere packing code" [16], "Three years ago, Maryna Viazovska, of the 
Swiss Federal Institute of Technology in Lausanne, dazzled mathematicians by identifying the densest way to pack equal-sized spheres in eight- and 24-dimensional space... Now, she and her coauthors have proved something even more remarkable" [17] etc.

Furthermore, the analysis of modern media content testifies to powerful image forming potential of Ukrainian biological and medical scientific schools represented by I. Mechnikov, D. Zabolotny, O. Bogomolets, V. Vernadsky, O. Brovarets, M. Rodnina etc.

In particular, a Ukrainian I. Mechnikov (1845-1916) - the Nobel Prize winner for works on immunity (1908), the author of the phagocytic theory of immunity, one of the founders of experimental morphology - is considered a precedent figure in world science. We note that the scientist's figure is also significant for modern society, which evidenced by numerous image publications about I. Mechnikov in media. Image forming linguistic markers in such media publications are evaluational constructions with positive semantics, i.e. paraphrases: "...although his best discoveries in many fields of biological science Mechnikov, who is still called the father of world gerontology, has made abroad, his roots are Ukrainian" [18], epithets: "He will become the first scientist in the world to discover the human body's defense mechanisms. A scientist from Slobozhanshchina will notice under microscope the so-called phagocytes - cells of the human body that absorb and digest foreign viruses and bacteria. This study was so revolutionary that even the well-known biologist Robert Koch, who discovered tuberculosis, called it a tumultuous fantasy" [19], "The ideas of a talented scientist still contribute to the development of various fields of biology and medicine" [18] etc.

D. Zabolotny, a well-known epidemiologist, microbiologist, founder of the Institute of Microbiology and Virology of the National Academy of Sciences of Ukraine, President of Ukrainian Academy of Sciences (1928-1929) also made a significant contribution to the formation of a positive image of Ukraine and Ukrainian science. The scholar's works devoted to the study of infectious diseases such as plague, cholera, syphilis brought him world recognition. We note 
that scientific achievements of D. Zabolotny are highly appreciated in modern media, which is presented by a stylistic resource of metaphors ("An epidemiologist Danylo Zabolotny rescued humanity") [20], epithets ("A person of high humanistic ideals Danylo Zabolotny"), [21], hyperboles ("Danylo Zabolotny is a genius of Ukrainian science. His life story is the best guide for those who want to reach heights in their business") [22] etc.

The figure of a prominent scientist, academician, founder of the school of pathophysiology, endocrinology and gerontology O. Bogomolets (1881-1946) is as well symbolic for Ukrainian science. The researcher's scientific discoveries are highly appreciated in media, which emphasize the relevance of his research. At the linguistic level this is expressed in emotionally-evaluative epithetical and metaphorical constructions with expressively positive semantics, e.g. "O. Bogomolets is a Ukrainian who extended life of humanity", "His works on prolonging life, combating many incurable diseases at that time became a huge scientific breakthrough which served as a fundamental basis for modern medicine" [23], "O. Bogomolets is an outstanding figure in Ukrainian history. It was he who for the first time in the history of the world invented the principle of donor blood preservation" [24] etc.

The discovery of the youngest DSc in Ukraine, a biophysicist O. Brovarets (born 1986) is of great importance for the construction of a positive image of our country. The researcher succeeded in calculating the pattern by which mutant chromosome pairs are embedded in human DNA resulting in deadly diseases such as cancer. The scientist's scientific achievements were highly appreciated in world and Ukrainian media. The main image forming markers in media texts on this subject are hyperboles, metaphors and epithets with evaluative meaning: "To make a world-wide discovery at the age of 29? Olga Brovarets proves that this is possible in Ukraine" [25], "A Ukrainian has made a sensational discovery that can save humanity from cancer and other diseases" [26], "Sensational discovery of a Ukrainian scientist, the doctor of science Olga Brovarets in microbiology has excited the whole 
world, because it gives hope for a complete recovery from cancer and many other diseases which cause mutations" [27] etc.

It should be noted that today the positive image of our country is also shaped by those Ukrainian scientists who work abroad. For instance, in Germany innovative biochemistry research is conducted by prof. M. Rodnina (born 1960) whose works are devoted to the study of the mechanisms of ribosome function during translation. M. Rodnina has received the Hans Neurath Award in 2015 and the Gottfried Wilhelm Leibniz Prize in 2016. The Gottfried Wilhelm Leibniz Prize is the largest prize in the world which is awarded to scientists for outstanding scientific achievements and is second only to the Nobel Prize. Most of image publications devoted to the scholar's investigations contain image component that in linguistics can be expressed by lexemes with evaluative semantics, epithetical and metaphorical constructions: "Professor from Ukraine Marina Rodnina was awarded the most prestigious scientific award" [28], "One of the most prestigious awards went to Marina Rodnina", "A Ukrainian professor Rodnina won the Leibniz Prize, one of the most prestigious scientific awards in the world" [29], "A good practice example and a role model: Marina Rodnina" [30], "Prof. Marina Rodnina (The Max Planck Institute for Biophysical Chemistry, Göttingen, Germany) was awarded the ERC Advanced Grant" [31] etc.

Thus, the research material proves that the creation of successful image strategies is a multidisciplinary scientific problem. The enormous Ukrainian image forming potential, especially scientific, requires professional linguistic analysis and a positive presentation in media. In this context, media linguistic imageology, that is able to explain linguistic mechanisms for constructing effective image texts, seems to be one of the most promising research directions of modern neolinguistics.

\section{REFERENCES}

1. Alekseeva, E. (2017). Russia's image strategy as a factor of ensuring its national interests [Imidzhevaja strategija Rossii kak faktor obespechenija ee nacional'nyh interesov]. Gumanitarnyj vestnik. http://dx.doi.org/ 10.18698/2306-8477-2017-02-417 [in Russian]. 
2. Bourdieu, P. (2001). Practical Reason [Prakticheskij smysl]. Institute of Experimental Sociology, 562 p. [in Russian].

3. Cheddad, A.,Condell, J.,Curran, K., McKevitt, P.(2010). A new digital image security strategy: Steganoflage.Waterfront Hall, Belfast, Northern Ireland [in English].

4. Díaz Rodríguez, P., Santana Talavera, A., Rodríguez Darias, A. (2017). Image on internet as a strategy of rejuvenation: Virtual expectations. Quaderns de l'Institut Catala d'Antropologia. 32, 167-193 [in English].

5. Hsiang-Ming Lee, Ching-Chi Lee, Cou-Chen Wu (2011). Brand image strategy affects brand equity after M\&A. European Journal of Marketing, 45 (7/8). https://doi.org/10.1108/03090561111137624 [in English].

6. Junevičius, A., Mindaugas, P. (2015). The importance of strategy for forming state image: comparative analysis of Lithuanian, Estonian and Finnish cases. Procedia - Social and Behavioral Sciences, 213, 86-91. https://doi.org/10.1016/j.sbspro.2015.11.408 [in English].

7. Kadek Dwi Cahaya Putra (2010). Image restoration strategy of Bali tourism crises. The Journal of Communication Sciences, 5 (1) [in English].

8. Nye, J. (1990). Bound to lead: The changing nature of American power. New York, Basic Books.

9. Pocheptsov, G. (2001). Imageology [Imidzhelogija]. Kyiv, 698 p. [in Russian].

10. Vasylenko, I. (2014). Image strategy of modern Russia [Imidzhevaja strategija sovremennoj Rossii]. 390-414 [in Russian].

11. Vasylenko, I. (2015). The role of "soft power" technologies in shaping Russia's image strategy [Rol' tehnologij "Mjagkoj sily"v formirovanii imidzhevoj strategi Rossii]. Kontury global'nih transformacij: politika, jekonomika, pravo. 1 (39), 28-34 [in Russian].

\section{RESOURCES}

12. http://holos.fm/page/golos-istoriyi-24-veresnja-matematik-mihajloostrogradskij

13. https://www.encyclopedia.com/science/dictionaries-thesaurusespictures-and-press-releases/ostrogradsky-mikhail-vasilievich

14. https://www.facebook.com/Voronoi/posts/234829840591820/

15. https://rubryka.com/2019/05/18/maryna-v-yazovska-proryv/

16. http://www.icm2018.org/wp/2018/08/02/how-maryna-viazovskacracked-the-sphere-packing-code/ 
17. https://www.quantamagazine.org/universal-math-solutions-indimensions-8-and-24-20190513/

18. http://razom.media/illya-mechnikov/

19. https://24tv.ua/illya_mechnikov_ukrayinskiy_biolog_yakiy_doviv_ korisnu diyu yogurta n919125

20. https://svoboda-news.com/svwp/епідеміолог-данило-заболотнийрятув/

21. https://parafia.org.ua/person/zabolotnyj-danylo/

22. http://vsviti.com.ua/ukraine/61100

23. http://heroes.profi-forex.org/ua/bogomolec-oleksandr-oleksandrovich

24. https://blogs.pravda.com.ua/authors/bogomolec/5b98d193cb968/

25. https://www.facebook.com/censor.net/posts/1273423849374887

26. https://tsn.ua/nauka_it/ukrayinka-zrobila-sensaciyne-vidkrittya-yakemozhe-vryatuvati-lyudstvo-vid-raku-ta-inshih-hvorob-863400.html

27. https://www.linkedin.com/pulse/miracle-discoveries-new-resultsresearch-dna-help-bondarenko-ph-d-

28. https://www.obozrevatel.com/ukr/abroad/63874-znaj-nashihprofesor-z-ukraini-udostoilasya-najprestizhnishoi-naukovoi-premii.htm

29. http://meest-online.com/science/inventions/odna-z-najprestyzhnishyhnahorod/

30. https://academialeaks.wordpress.com/2018/07/07/a-good-practiceexample-and-a-role-model-marina-rodnina/

31. http://ukrainet.eu/2018/05/10/erc-advanced-grant-for-marina-rodnina/

Дата надходження до редакції - 06.10.2019 Дата затвердження редакцісю - 02.11.2019 